\title{
Protein Arginine Methyltransferase 5 Inhibitor GSK3326595
}

\author{
National Cancer Institute
}

\section{Source}

National Cancer Institute. Protein Arginine Methyltransferase 5 Inhibitor GSK3326595.

NCI Thesaurus. Code C142177.

An orally available, selective small molecule inhibitor of protein arg inine methyltransferase 5 (PRMT 5), with potential antiproliferative and antineoplastic activities. Although the mechanism of action has not been completely determined, PRMT 5 inhibitor GSK3326595 binds to the substrate recog nition site of PRMT 5 following oral administration and inhibits its methyltransferase activity, which decreases the levels of both monomethylated and dimethylated arg inine residues in histones $\mathrm{H} 2 \mathrm{~A}, \mathrm{H} 3$ and $\mathrm{H} 4$ and modulates the expression of genes involved in several cellular processes, including cell proliferation. Therefore, this agent may increase the expression of antiproliferative genes and/or decrease the expression of genes that promote cell proliferation and may lead to decreased growth of rapidly proliferating cells, including cancer cells. PRT M5, an arginine methyltransferase that can catalyze the formation of both omega- $\mathrm{N}$ monomethylarginine (MMA) and symmetrical dimethylarginine (SDMA) on histones and a variety of other protein substrates, is overexpressed in several neoplasms. 